\title{
Facial Soft Tissue Injuries in Pediatric Patients
}

\author{
Sam Schild, MD ${ }^{1,2}$ Tatiana Reis Puntarelli, MD ${ }^{3}$ Margarita delaPena, MD ${ }^{3}$ Adam Johnson, MD, $\mathrm{PhD}^{4}$ \\ Sydney C. Butts, MD, FACS $1,2,5$
}

${ }^{1}$ Department of Otolaryngology, SUNY Downstate Health Sciences

University, Brooklyn, New York

${ }^{2}$ Department of Otolaryngology, Kings County Hospital Center, Brooklyn, New York

${ }^{3}$ Department of Anesthesiology, SUNY Downstate Health Sciences University, Brooklyn, New York

${ }^{4}$ Department of Otolaryngology, University of Arkansas Medical School, Arkansas Children's Hospital, Little Rock, Arkansas

${ }^{5}$ Division of Facial Plastic and Reconstructive Surgery; Department of Otolaryngology, SUNY Downstate Health Sciences University, Brooklyn, New York

Address for correspondence Sydney C. Butts, MD, FACS, Department of Otolaryngology, SUNY Downstate Health Sciences University, 450 Clarkson Avenue, Box 126, Brooklyn, NY 11203 (e-mail: sydbutts@gmail.com).

Facial Plast Surg 2021;37:516-527.

\begin{abstract}
\section{Keywords}

- pediatric dog bites

- pediatric facial trauma

- postnatal facial injuries

Soft tissue injuries of the head and neck are a common reason for medical evaluation and treatment in pediatric populations with some unique and important considerations when compared with adults. The incidence and type of injuries continue to evolve with the adoption of new safety measures, technology advancements, and education of the general population. The goal of this article is to provide the reader with a thorough understanding of the evaluation and management of pediatric soft tissue trauma including the initial workup, physical examination, appropriateness of antimicrobial therapy, and setting for surgical repair. Additionally, the pediatric anesthetic considerations for evaluation and repair in regard to local anesthesia, sedation, and general anesthesia are described in detail. There is a focus on dog bites, perinatal injuries, and child abuse as these entities are distinctive to a pediatric population and have particular management recommendations. Lastly, application of the reconstructive ladder as it applies to children is supported with specific case examples and figures. Although there are many parallels to the management of soft tissue injury in adults, we will highlight the special situations that occur in pediatric populations, which are imperative for the facial plastic and reconstructive surgeon to understand.
\end{abstract}

Trauma is the leading cause of morbidity and mortality in the pediatric population (aged 0-18) worldwide with craniofacial trauma a major component. ${ }^{1-4}$ Soft tissue injuries of the head and neck are a common reason for medical evaluation and treatment in pediatric populations. ${ }^{5}$ Prominence of the cranium in infants and young children increases the likelihood of injury to this region. ${ }^{3,6}$ However, facial fractures are less frequent compared with adults due to the elastic nature of the skeleton in the pediatric population and the relationship of the midface and mandibular skeleton to the skull base. ${ }^{1,6,7}$ The incidence and type of injuries continue to evolve with the adoption of new safety measures, technology advancements, and education of the general population. ${ }^{4,8} \mathrm{~A}$ high priority must be placed on the prevention of pediatric facial trauma considering the accidental nature of many pediatric soft tissue injuries. Helmets, protective gear, car seats, and child-safety locks are among the many prevention measures available to decrease occurrences and severity of facial trauma. ${ }^{6,9,10}$

\section{Mechanisms of Injury}

\section{Motor Vehicle Accidents and Sports}

The etiology and mechanism of soft tissue injury include some unique considerations in the pediatric population. The
Issue Theme Facial Soft Tissue Injury and Healing; Guest Editor: Sydney C. Butts, MD, FACS (c) 2021. Thieme. All rights reserved. Thieme Medical Publishers, Inc., 333 Seventh Avenue, 18th Floor, New York, NY 10001, USA
DOI https://doi.org/ 10.1055/s-0041-1727246. ISSN $0736-6825$. 
most common etiologies include motor vehicle accidents and falls. ${ }^{1,11}$ Accidents due to sporting activities vary based on age and region of the country and include injuries involving bicycles, scooters, all-terrain vehicles, and contact sports. ${ }^{6,9,12-14}$ A review of the National Electronic Injury Surveillance System, that includes 764,293 emergency department visits related to contact sports and facial injuries revealed that basketball-related injuries accounted for the majority of visits at $46.6 \%{ }^{14}$ The use of personal protective equipment in sports such as football or lacrosse may explain the lower incidence of facial injuries among participants in these sports. ${ }^{14}$

\section{Dog Bites}

The shorter stature of toddlers, their curiosity, and their inability to defend themselves when approaching pets can explain their vulnerability to animal bite wounds involving the face ${ }^{15}$ In the United States, dog bites represent the large majority of animal bites with $\sim 1$ to 2 million attacks annually and up to $90 \%$ of animal bites presenting to emergency departments. ${ }^{16,17}$ Across multiple studies, the majority of pediatric patients presenting with dog bites were schoolaged children (6-12 years), male, and presenting in June or July. ${ }^{15,17,18}$ Injuries in infants (birth to 1 year) and preschoolers ( $2-5$ years) usually involve the face (53.5\%), unlike older children who sustain extremity injuries. ${ }^{15}$ Dog owners have a role to play in the prevention of bite injuries by ensuring proper training and socialization of the pet. ${ }^{5,19}$ Small children and babies should not be left alone with a dog and parents must exercise caution if their child is going to be in contact with a dog unfamiliar to them. ${ }^{5}$

From a public health and medicolegal standpoint, understanding trends in dog bite injuries could potentially decrease the incidence and morbidity of attacks. The types of dogs most commonly implicated and the specific behavioral traits of dogs that bite people are variables that may identify breeds posing the greatest risk to the public. ${ }^{20}$ While studies have identified pit bull terriers, German shepherds, and rottweilers as common offenders, there are barriers to this type of data gathering through law enforcement and other legal channels. ${ }^{15,18}$ Legal hurdles make it difficult to prove and designate certain breeds as more dangerous due to the inability to establish the specific genetic makeup of breeds involved in bite injuries. Dog registries are uncommon and dog bite reporting is not required by state law in many regions of the United States. ${ }^{15}$ Legislation that would enact regulations for certain breeds of dogs has encountered resistance among some dog owners. ${ }^{15}$

\section{Perinatal Soft Tissue Injuries}

A unique type of pediatric soft tissue trauma includes injuries occurring in the perinatal period due to birth trauma and other injuries occurring in the immediate postpartum period. ${ }^{21,22}$ One high-risk group are children requiring additional medical care in the neonatal intensive care unit (NICU), who may also be premature, low birth weight, or both. These patients have thin facial soft tissues that are vulnerable to pressure injuries from medical equipment. ${ }^{21}$ We will review several cases of perinatal nasal injuries secondary to nasal continuous positive airway pressure (nCPAP) treatment and discuss the importance of training staff to implement primary prevention measures and recognize the signs of evolving injuries.

\section{Child Abuse}

Children, especially preadolescents, are at higher risk of abuse or neglect. ${ }^{23}$ Physicians involved in the evaluation and care of patients with soft tissue facial trauma must always be on high alert for a presentation suspicious for abuse. An estimated 25\% of children are victims of some form of abuse or neglect during their life, with 1 in every 7 experiencing it in the past year. ${ }^{23}$ Clinical screening on initial presentation represents secondary prevention and is essential to identifying these patients at the earliest possible stage. There are many abuse screening tools available including the Pediatric Brain Injury Research Network (PediBIRN); Predicting Abusive Head Trauma (PredAHT), Pittsburgh Infant Brain Injury Score (PIBIS), and the TEN-4-FACESp Bruising Clinical Decision Rule. ${ }^{23}$ Multiple bruising injuries, oral injuries, and burn injuries are considered a "positive" screen. ${ }^{23}$ The TEN-4-FACESp Bruising Clinical Decision Rule is a validated scale for identifying children at high-risk of physical abuse and is applied to children under 4 years of age. TEN refers to torso, ear, and neck and FACES refers to frenulum, angle of jaw, cheek, eyelid, subconjunctiva, or patterned bruising or any bruising on an infant 4 months of age or younger.

Other important details about the injuries to determine from history gathering include whether the bruising or petechia displays a geometric shape or recognizable pattern and if there is a clear, plausible story to account for the bruising. Reporting suspected child abuse to Child Protective Services is mandatory in all US states, Washington, D.C., and the US territories. ${ }^{23}$ The 7-year-old patient shown in - Fig. 1 presented for the evaluation of a cauliflower ear deformity following an auricular hematoma as a result of abuse. Once in a new, safe home environment, her family and the patient herself desired reconstruction. The extensive fibrosis of the conchal bowl caused narrowing of the proximal external auditory canal. The stigma of the deformity was a constant reminder of the abuse and was another important factor in deciding to move forward with reconstruction. Debulking of the fibrotic tissues was performed in a two-staged procedure, addressing the conchal bowl first (-Fig. 2) via an anterior approach. Two months later, fibrosis of the antihelix and scaphoid fossa was debulked utilizing an incision placed along the posterior aspect of the helical rim and elevating the skin flap anteriorly for exposure (-Fig. 2)..$^{24,25}$ This case shows how a patient of school age was able to actively participate in surgical decision-making and how the outcome had a positive psychological impact in a victim of abuse (-Fig. 3).

\section{History and Physical Examination}

Several factors make history gathering and performance of the physical examination more challenging than in an adult patient. In very young children, the history must be obtained from a caregiver or witness who should provide the time, 


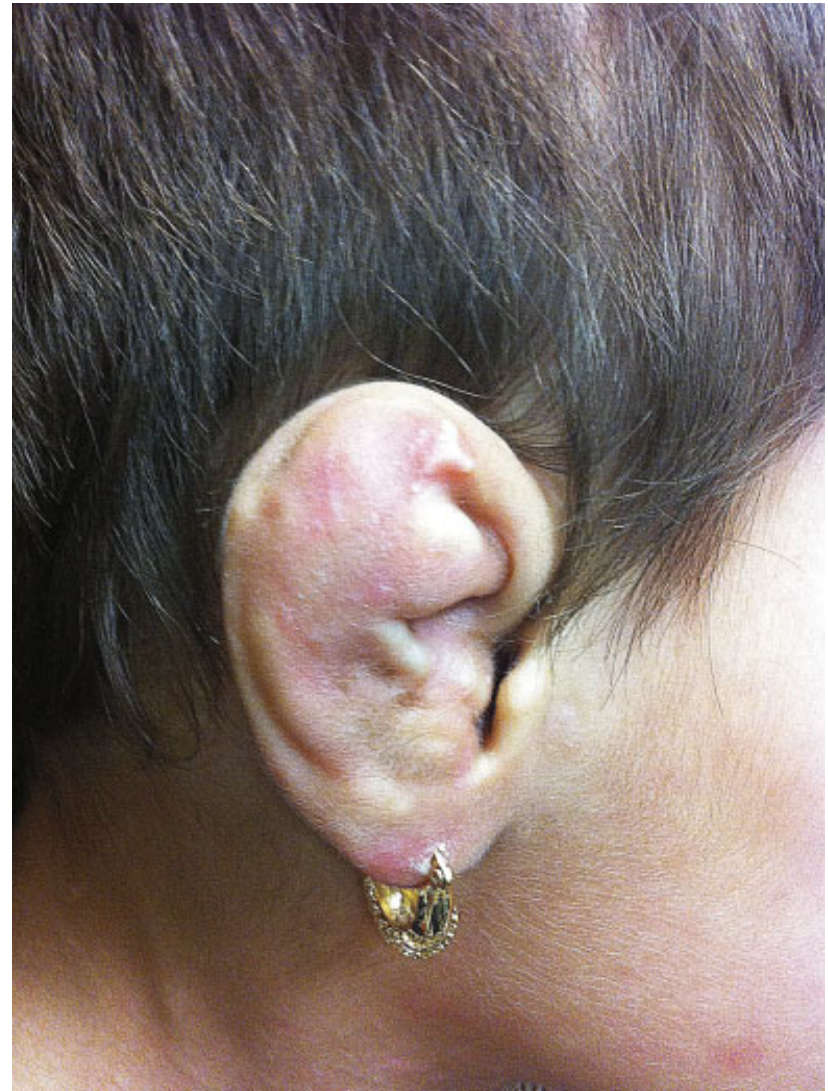

Fig. 1 Cauliflower ear deformity in a 7-year-old patient after child abuse. Reproduced with permission from Butts et al. ${ }^{74}$

mechanism, and details of the injury. This process becomes more challenging in an unwitnessed event. Regardless of the mechanism, these situations tend to be traumatic and upsetting for families. In a trauma setting, there are potentially additional injuries and a thorough survey by the evaluating trauma team must be performed, ensuring that the airway, breathing, and circulation are stable. When an intracranial injury is present, neurosurgical evaluation is mandatory. Soft tissue injuries involving periorbital tissues or the globe itself require an ophthalmological evaluation. Though not the focus of this article, it is important to highlight the impor-

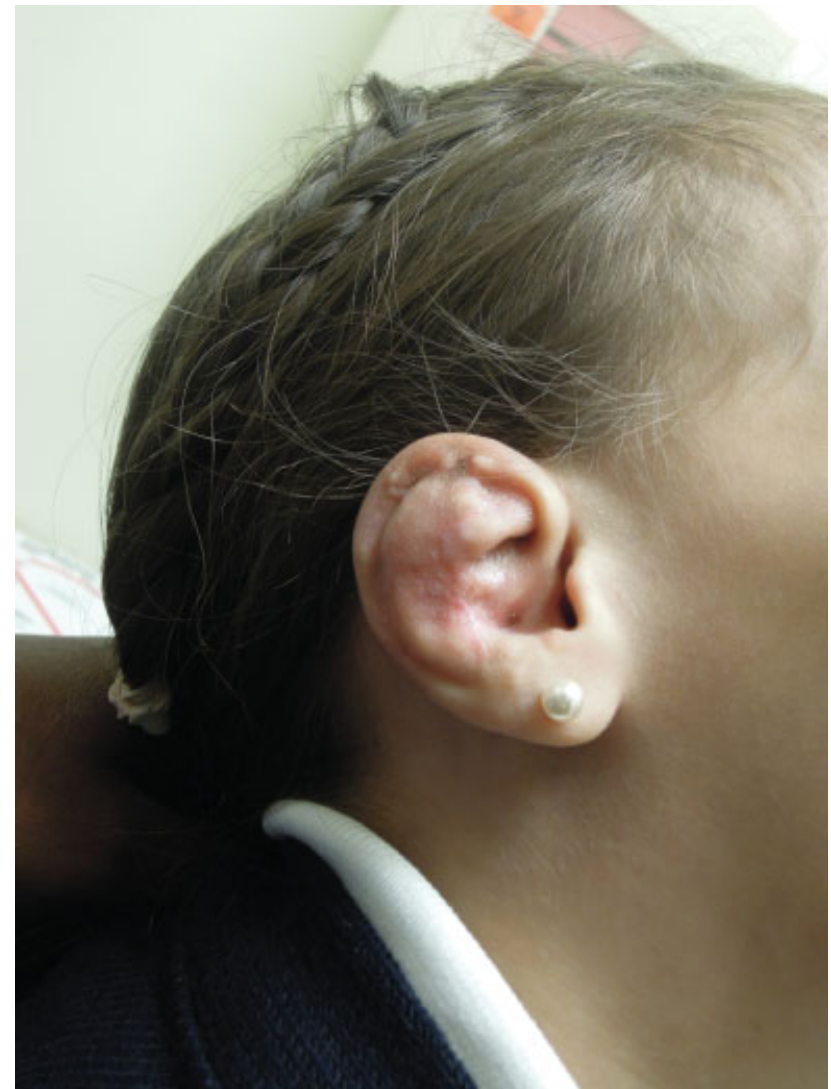

Fig. 3 Postoperative view after two-staged repair of cauliflower ear deformity.

tance of computed tomography scan imaging in any patient that could possibly have a fracture of the craniomaxillofacial skeleton.

All soft tissue injuries should be managed in an organized fashion on initial presentation. Classification of the etiology, location, size, and depth of the wound is essential in surgical planning and patient counseling. ${ }^{5}$ This examination should include evaluation of sensation and motor function. Bleeding associated with the soft tissue injuries can be controlled in the emergency department (ED) safely by packing the wound. More significant blood loss should be controlled in the operating
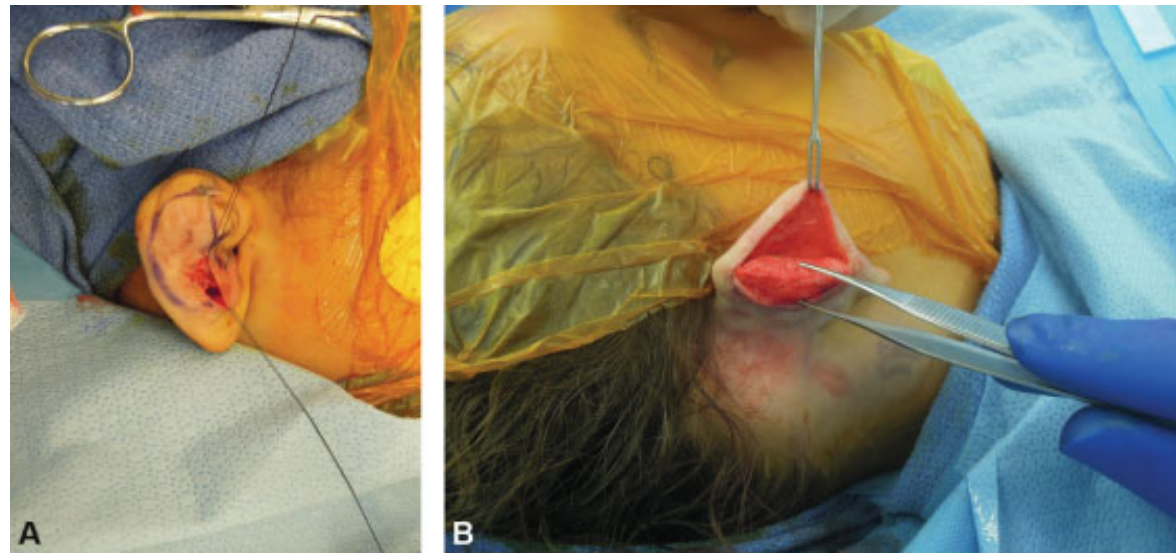

Fig. 2 Otoplasty of cauliflower ear deformity: (A) Stage 1: anterior approach to conchal bowl. (B) Stage 2, posterior approach to helical rim. 
room. Clamping vessels or soft tissue outside of the operative setting, especially in a bloody field, risks the possibility of injury to surrounding structures.

Copious irrigation, especially of wounds with significant foreign material, is of paramount importance in preventing wound infection. Devitalized tissue, when present, should be debrided judiciously with a focus on maximal preservation of soft tissue. ${ }^{5}$ Photo documentation is an important aspect of documenting characteristics of the wound and can be important in serial assessments of the wound over the course of staged treatments and if there is any concern for child abuse. $^{5}$

Thinner subcutaneous tissues in children offer less cushion and a seemingly superficial laceration may in actuality represent a complex tissue injury. One must not hesitate to fully assess the depth of wounds while cleaning the wound to avoid missing the full extent of the injury. In some instances, the examination may require anesthetic techniques to accomplish these goals. The case in - Fig. 4 is an example of a toddler who presented to the emergency department after a fall at home against the edge of a coffee table. Exploration of the wound in the operating room revealed that the laceration of the columella extended to both medial crura. Repair of the medial crura and primary closure of the columellar skin was then performed in the operating room (-Fig. 4).

The guidelines for prescribing antimicrobial therapy have varied over time but more recent evidence-based recommendations are available based on organisms typically cultured from wounds that became infected. ${ }^{26}$ Simple wounds that have been cleaned, irrigated, and closed adequately do not routinely require systemic antibiotics but topical antimicrobial agents have been shown to provide a moist environment for healing and also decrease chance of infection. 5,27 Prophylactic systemic antibiotics are indicated in specific cases, namely animal or human bites, deep contaminated wounds, or injuries with delayed presentation. ${ }^{5,26}$ Coverage of commu- nity-acquired methicillin-resistant Staphylococcus aureus strains (MRSA) should be considered in areas where there are high rates of antibiotic-resistant bacteria. ${ }^{5,28}$ The American Academy of Pediatrics Red Book Report of the Committee on Infectious Diseases provides a guideline for antimicrobial therapy in soft tissue trauma situations. ${ }^{29}$ In general, the wound status (clean, clean-contaminated, contaminated, infected) and mechanism of injury are the main considerations for antibiotic prophylaxis and duration of therapy. Cat bites, though much less frequent than dog bites, are also prone to infection. ${ }^{26,29}$ As most infected mammalian bite wounds are polymicrobial in nature, the most common initial treatment of choice is amoxicillin-clavulanic acid. However, the addition of trimethoprim-sulfamethoxazole, which is effective against $S$. aureus (including MRSA), Pasteurella multocida, and Eikenella corrodens, should be considered in animal bite wounds. ${ }^{26}$ For fresh wounds, a 3- to 5-day course of antibiotic therapy is generally sufficient, but more severe or infected wounds may require a 7 - to 10-day course of therapy.,29

For animal bite wounds, potential transmission of rabies must be considered from wild animals, especially bats or carnivores, or from a domestic animal with uncertain immunization status. ${ }^{29}$ Improved canine vaccination programs and stray animal control has led to a marked decrease in domestic animal rabies cases in the United States since World War II. ${ }^{30}$ The Advisory Committee on Immunization Practices and World Health Organization recommendations for post exposure prophylaxis, which includes human rabies immunoglobulin and vaccination, depend on the availability of the animal for observation or rabies testing. ${ }^{30}$ For most other carnivores (e.g., skunks, raccoons, and foxes) and bats, immediate prophylaxis should be considered unless the animal has been proven negative by a laboratory test. ${ }^{30}$ Notification of public health officials is recommended if there is uncertainty. Assessment for hepatitis B virus infection and risk of human deficiency virus should be considered in human bite wounds. ${ }^{29}$
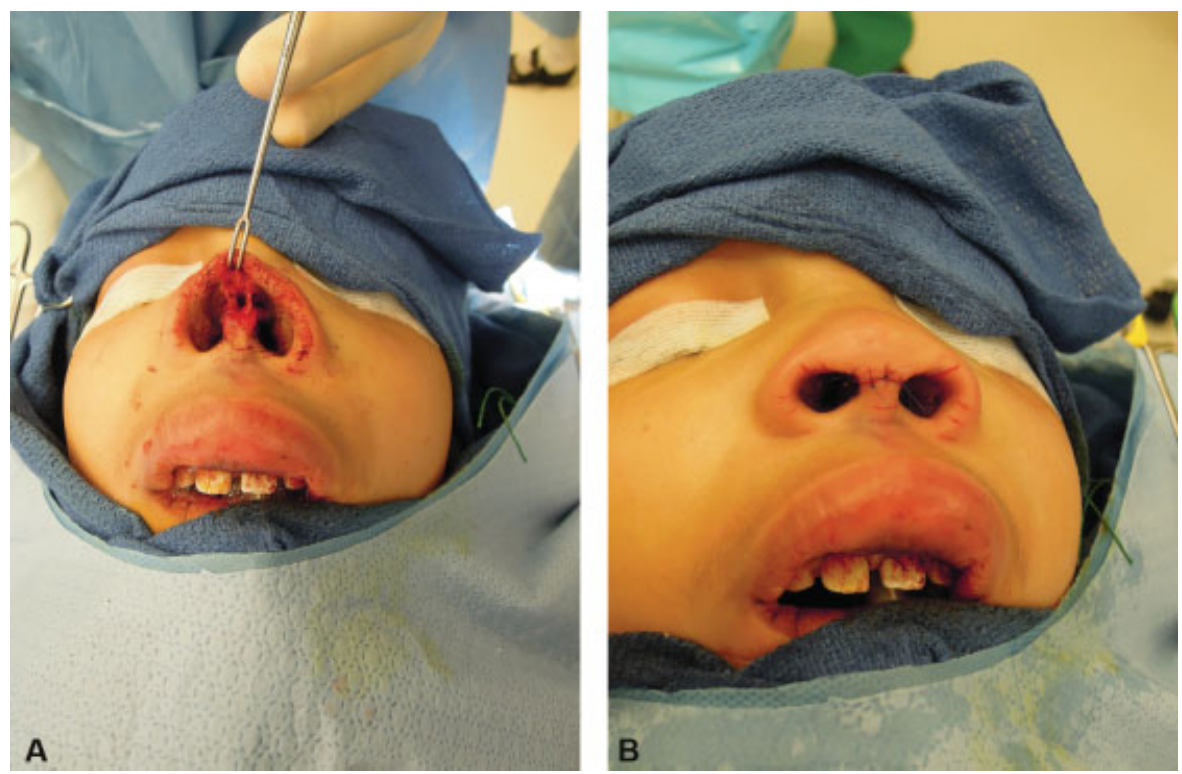

Fig. 4 Columellar injury with deep extension to medial crura in toddler after fall: (A) Preoperative view and (B) postoperative view. Reproduced with permission from Butts et al. $^{74}$ 
In open or contaminated (e.g., dirt, soil, or saliva) wounds, determination of the tetanus immunization status and early treatment of the wound are important steps. ${ }^{31}$ The risk of tetanus infection is highest in puncture wounds, crush injuries, avulsions, and burns. ${ }^{31}$ Even in clean wounds, tetanus toxoid should be administered if the patient has had 3 or fewer immunizations or it has been 10 years since the last immunization. $^{31}$

The decision as to the setting for repair-in the emergency department/outpatient office setting or the operating roommust take several factors into account. In children, repair in the emergency room can be challenging due to movement and intolerance of pain. Resources and staff who can perform sedation in the ED should be available. ${ }^{32,33}$ This factor is essential for safe wound repair. Injuries that should be considered for repair in the operating room include soft tissue injury or loss involving multiple facial subunits or a large surface area loss; active bleeding that cannot be controlled with conservative measures; inability to fully assess or complete the repair with local or conscious sedation; need to repair other structures including nerves, vessels, or muscle or wounds that involve full-thickness tissue breaches. We will review the anesthesia options, from topical and intralesional injection to conscious sedation and general anesthesia.

\section{Management}

\section{Pediatric Anesthesia}

Principles of pediatric anesthesia for soft tissue injuries must be considered in the context of an unscheduled procedure. Time is of the essence due to the urgent nature of the patient presentation and its emergent characteristic. Sedation in children is often administered to relieve pain and anxiety as well as to obtain immobility as to allow for safe completion of a procedure. ${ }^{34}$ A child's ability to control their own behavior to cooperate for a procedure depends on the chronological age and the cognitive/emotional development. ${ }^{35}$

Many brief procedures may be accomplished with distraction, parental presence, and guided imagery techniques, along with the use of topical/local anesthetics and minimal sedation, if needed. However, longer procedures that require immobility, especially when involving children younger than 6 years old or those with developmental delay, often require an increased depth of sedation. ${ }^{34}$ Prevention of pulmonary aspiration is part of the preparation of a patient who will undergo sedation because upper airway protective reflexes may be impaired. There are different guidelines concerning fasting periods. The American College of Emergency Physicians recommends a baseline fasting of 3 hours and then variable timing depending on the urgency of the procedure and planned depth of sedation. ${ }^{34}$ The American Society of Anesthesiology (ASA) determines fasting periods of 2 hours for clear liquids, 4 hours for breast milk, 6 hours for infant formulas, and 8 hours for solid foods for nonemergent cases. ${ }^{36}$

A hallmark of procedural sedation is the concept of a sedation continuum, that is, that all sedatives and opioids, depending upon dose and patient response, are capable of producing any sedation depth along the scale from minimal sedation to general anesthesia. ${ }^{34}$ The characterization of depth of sedation levels is conventionally based on responsiveness to verbal or tactile stimulation, and has secondary ventilatory characteristics.

Minimal sedation or anxiolysis is a drug-induced state during which patients respond normally to verbal commands. Although cognitive function and physical coordination may be impaired, airway reflexes, ventilatory, and cardiovascular functions are unaffected. ${ }^{37}$ Moderate sedation/analgesia ("conscious sedation") is a drug-induced depression of consciousness during which patients respond purposefully to verbal commands, either alone or accompanied by light tactile stimulation. Deep sedation/analgesia is a drug-induced depression of consciousness during which patients cannot be easily aroused but respond purposefully following repeated or painful stimulation. The ability to independently maintain ventilatory function may be impaired. Patients may require assistance in maintaining a patent airway, and spontaneous ventilation may be inadequate. Cardiovascular function is usually maintained. ${ }^{37}$

It is common for children to pass from the intended level of sedation to a deeper, unintended one, making the concept of rescue essential to safe sedation. Practitioners of sedation must have the skills to rescue the patient from a deeper level than that intended for the procedure. ${ }^{35}$ Patients who are ASA classes I and II are generally considered appropriate candidates for minimal, moderate, and deep sedation. Children in ASA classes III and IV, children with special needs, and those with anatomic airway abnormalities or moderate-to-severe tonsillar hypertrophy present issues that require additional considerations, especially for moderate and deep sedation. ${ }^{38}$ Children younger than 6 years old, in particular those younger than 6 months old, are at greatest risk of adverse events. ${ }^{39}$ They are particularly vulnerable to the sedating medication's effects on respiratory drive, airway patency, and protective airway reflexes. ${ }^{40}$

During procedural sedation and analgesia, a nurse or other qualified individual should be present to continually observe and monitor the patient, in addition to the provider performing the procedure. ${ }^{34}$ The practitioner who uses sedation must have immediately available facilities, personnel, and equipment to manage emergency and rescue situations. ${ }^{35}$ The most common complications of sedation involve compromise of the airway or depressed respirations resulting in airway obstruction, hypoventilation, laryngospasm, hypoxemia, and apnea. ${ }^{41}$ Rescue techniques require specific training and skills. ${ }^{34,35}$ These include the ability to open the airway, suction secretions; provide CPAP; perform successful bag-valve-mask ventilation; insert an oral airway, a nasopharyngeal airway, or a laryngeal mask airway; and, rarely, perform tracheal intubation. An emergency cart or kit must be immediately accessible. It must contain the necessary age- and size-appropriate equipment for resuscitation. ${ }^{35}$

Before the administration of sedative medications, a baseline determination of vital signs should be documented. There should be continuous monitoring of oxygen saturation and heart rate. ${ }^{35}$ Ventilatory adequacy is verified through close observation of the airway, supplemented with physiologic 
monitoring of oxygenation (pulse oximetry) and ventilation (capnography). ${ }^{34}$ Monitoring of blood pressure is also required but may be postponed until the child is sedated if the cuff insufflation may cause arousal or agitation.

The child who has received moderate or deep sedation must be observed in a suitably equipped recovery area. Such an area must have the capacity to deliver $>90 \%$ of oxygen and positive-pressure ventilation (bag-valve-mask), as well as a functioning suction apparatus. If the patient is not fully alert, oxygen saturation and heart rate should be continuously monitored. The child should be observed until complete return to baseline. ${ }^{35} \mathrm{~A}$ simple evaluation tool may be the child's ability to remain awake for at least 20 minutes when placed in a quiet environment. ${ }^{42}$ The practitioner responsible for the treatment of the patient and/or the administration of drugs for sedation must be familiar with the drugs they intend to use and competent to manage complications $34,43,44$ (see - Table 1).

\section{Reconstructive Ladder in Children}

The reconstructive ladder that conceptualizes the order in which treatment options for soft tissue wounds should be considered can be utilized in pediatric patients in the way that it is in adults. There are unique factors in the pediatric patient population that compel the surgeon to think about the specific application of theses reconstructive guidelines. ${ }^{45}$ The reconstructive "finish line" in a pediatric patient is potentially on the order of years rather than months as one must factor in the role of continued facial growth that is not a variable in adult patients. The age at which the injury occurs may preclude single-stage reconstruction in lieu of staged procedures. Different levels of donor site morbidity for children, whether harvesting grafts or flaps, may impose limitations that do not exist in the adult patient. Parental concerns and the necessary compliance of a young patient can also influence the options that may be considered acutely. The psychological strain of an acute facial injury, while more challenging to quantify, should also be in front of mind for surgeons as they travel the journey to full rehabilitation of the injury with patients and their families.

Reconstruction of cleft lip/nasal deformities provides several lessons about the importance of surgical staging and the negative impact of scarring on future growth. ${ }^{46}$ The patient in - Fig. 5 had repair of a left unilateral cleft lip/nasal deformity and presented to our institution with several concerns including left nasal obstruction. An alotomy used to help medialize the nostril was brought into the alarfacial groove. Rather than the often-described lateral displacement of the nostril on the cleft side as a residual concern after repair, this patient's cleft-side nostril is stenotic. $^{47}$ This is possibly related to overly aggressive advancement of the ala and scarring at this important junction between the nose and the face. One important modification of cleft lip repair techniques has been to limit the extent of any incisions into the alar facial crease to prevent narrowing of the nostril and avoid the extent to which scar tissue can present an obstacle for growth of the nose. ${ }^{46,48,49}$
Time-tested descriptions that define the extent of soft tissue losses (skin/muscle/cartilage/mucosal lining/nerve) and the facial subunits involved can provide an initial understanding of the wound that may have to be modified if intraoperative exploration is undertaken. Classification schemes of complex facial soft tissue trauma secondary to dog bites have been proposed. ${ }^{50}$ As seen in - Fig. 6, transection of the facial nerve can result from penetrating wounds of the cheek. Nerve exploration is indicated if the initial assessment reveals weakness of all or individual branches of the facial nerve. Immediate repair of the facial nerve via primary neurorrhaphy or with a nerve graft if tension free closure is not possible will yield the best outcome. ${ }^{51}$

Soft tissue injuries that result in tissue loss are some of the most challenging encountered in soft tissue facial trauma. Immediate skin grafting may be the most appropriate first step with plans for delayed flap closure. The availability of dermal allografts provides an excellent option in the right patient as donor site morbidity is avoided and scar contracture can be minimized until definitive soft tissue repair is scheduled. - Fig. 7 shows a patient who suffered a dog bite to the left perioral area. An allograft (NEOX ${ }^{\circledR}$ https:// amnioxmedical.com/neox-wound-allograft/) CORD 1K) was applied to this wound acutely. Secondary repair consisted of scar revision 6 months later. Rotational flaps may need to be performed primarily in the setting of tissue loss and in some instances, free tissue transfer is performed acutely when a massive tissue loss is present. Good results have been shown for both acute and delayed free tissue transfer in facial trauma patients. ${ }^{52,53}$

Perinatal nasal injury: Unique characteristics of the neonatal face include thin, pliable soft tissues amenable to molding that can improve congenital anomalies. Upper lip taping and nasoalveolar molding are examples of techniques used to improve upper lip and nasal form prior to definitive cleft lip repair. ${ }^{46}$ Neonatal ear molding with tapes or splints can significantly improve auricular contour in patients with congenital ear anomalies. ${ }^{54}$ The effectiveness of these techniques is related to the unique soft tissue qualities in neonates and infants that are receptive to molding and orthopaedic treatments. Though the pliability of the neonatal soft tissues can be harnessed as the basis of initial presurgical therapies, this exact quality makes facial soft tissues in neonates and infants more vulnerable to ulceration, pressure necrosis, and scarring when exposed to unplanned compression. ${ }^{21}$ Lacerations and resulting scarring, especially when not managed acutely, can result in secondary deformity in the growing face of a child.

The use of nCPAP for airway support in neonates in the NICU has resulted in fewer premature infants requiring prolonged airway intubation. ${ }^{22}$ The prongs of an nCPAP unit, which are firm and rigid, can compress the columella, ala, and soft tissue triangle of the nasal base causing a spectrum of injuries from ulceration to ischemic necrosis. ${ }^{21,22}$ Fibrosis from chronic irritation of prongs in the nose can inhibit growth of these areas, resulting in secondary deformities as the child's face grows. ${ }^{55}$ Patients will present for the evaluation of these injuries acutely if they are recognized by the NICU team or at later stages in life from 
522 Facial Soft Tissue Injuries in Pediatric Patients Schild et al.

Table 1 Drugs used for local infiltration and sedation

\begin{tabular}{|c|c|c|c|c|}
\hline \multicolumn{5}{|l|}{ Drugs } \\
\hline Drug & $\begin{array}{l}\text { Drug class/mechanism of } \\
\text { action }\end{array}$ & Dose/route & Duration of action & Comments \\
\hline Lidocaine & $\begin{array}{l}\text { Amide local anesthetic } \\
\text { stabilizes neuronal } \\
\text { membrane by binding to } \\
\text { voltage-gated sodium } \\
\text { channels }\end{array}$ & $\begin{array}{l}\text { Max dose: } \\
4.5 \mathrm{mg} / \mathrm{kg} \text { without epinephrine } \\
7 \mathrm{mg} / \mathrm{kg} \text { with epinephrine } \\
\text { Subcutaneous infiltration, field } \\
\text { blocks }\end{array}$ & Duration: $90-200$ min & $\begin{array}{l}\text { Maximum dose should be } \\
\text { calculated before } \\
\text { administration }^{43}\end{array}$ \\
\hline Bupivacaine & Amide local anesthetic & $\begin{array}{l}\text { Max dose: } \\
2.5 \mathrm{mg} / \mathrm{kg} \text { without epinephrine } \\
3 \mathrm{mg} / \mathrm{kg} \text { with epinephrine } \\
\text { Subcutaneous infiltration, field } \\
\text { blocks }\end{array}$ & $\begin{array}{l}\text { Duration: } \\
\text { 180-600 min }\end{array}$ & $\begin{array}{l}\text { Maximum dose should be } \\
\text { calculated before } \\
\text { administration }^{43}\end{array}$ \\
\hline $\begin{array}{l}\text { Lidocaine- } \\
\text { prilocaine }\end{array}$ & $\begin{array}{l}\text { Eutectic mixture of local } \\
\text { anesthetics (EMLA) } \\
2.5 \% \text { lidocaine and } 2.5 \% \\
\text { prilocaine cream }\end{array}$ & $\begin{array}{l}\text { Max surface area: Weight } \\
<10 \mathrm{~kg}: 100 \mathrm{~cm}^{2} \\
\text { Weight } 10-20 \mathrm{~kg}: 600 \mathrm{~cm}^{2} \\
\text { Weight >20kg: } 2000 \mathrm{~cm}^{2} \\
\text { Topical }\end{array}$ & $\begin{array}{l}\text { Onset: } 1 \mathrm{~h} \\
\text { Duration: Persists } 1-2 \mathrm{~h} \text { after } \\
\text { removal } \\
\text { Onset on mucosa: } 5-10 \mathrm{~min}\end{array}$ & $\begin{array}{l}\text { Should be applied under } \\
\text { occlusive dressing for at least } \\
\text { an hour } \\
\text { Absorption of excessive } \\
\text { prilocaine may cause } \\
\text { methemoglobinemia, if } \\
\text { applied on mucosal } \\
\text { surfaces } 44\end{array}$ \\
\hline $\begin{array}{l}\text { Lidocaine- } \\
\text { tetracaine }\end{array}$ & $\begin{array}{l}\text { Combination of amide } \\
\text { (lidocaine) and ester } \\
\text { (tetracaine) local anesthetic } \\
4 \% \text { Lidocaine, } 0.05 \% \\
\text { epinephrine, } 0.5 \% \text { tetracaine } \\
\text { (LET) gel }\end{array}$ & $\begin{array}{l}\text { Max area: Wounds up to } 6 \mathrm{~cm} \\
\text { Topical }\end{array}$ & $\begin{array}{l}\text { Onset: } \\
\text { 15-30 min }\end{array}$ & $\begin{array}{l}\text { Apply to nonmucosal wound } \\
\text { uncovered for } 20-30 \text { min } \\
\text { Avoid end-arteriolar parts of } \\
\text { the body (due to } \\
\text { epinephrine) }\end{array}$ \\
\hline Midazolam & $\begin{array}{l}\text { Benzodiazepine acts on the } \\
\text { GABA receptor (major } \\
\text { inhibitory neurotransmitter) }\end{array}$ & $\begin{array}{l}0.25-0.75 \mathrm{mg} / \mathrm{kg} \mathrm{PO} \\
0.05 \mathrm{mg} / \mathrm{kg} \mathrm{IV}\end{array}$ & $\begin{array}{l}\text { Onset: } \\
\text { 15-30 min } \\
\text { Duration: } 60-90 \mathrm{~min} \\
\text { Onset: } \\
\text { 1-3 min } \\
\text { Duration: } 60-90 \mathrm{~min}\end{array}$ & $\begin{array}{l}\text { Anxiolytic, provides } \\
\text { anterograde amnesia } \\
\text { No analgesic properties } \\
\text { If combined with opioids may } \\
\text { potentiate respiratory } \\
\text { depression } 44\end{array}$ \\
\hline Fentanyl & $\begin{array}{l}\text { Opioid, } 100 \text { times more } \\
\text { potent than morphine }\end{array}$ & $\begin{array}{l}0.5-2 \mu \mathrm{g} / \mathrm{kg} \text { IV } \\
1.5 \mu \mathrm{g} / \mathrm{kg} \text { intranasally }\end{array}$ & $\begin{array}{l}\text { Onset: } \\
1-2 \text { min } \\
\text { Duration: } 30-60 \mathrm{~min}\end{array}$ & $\begin{array}{l}\text { Analgesic response to } \\
\text { fentanyl is highly variable } \\
\text { May cause respiratory } \\
\text { depression, bradycardia, } \\
\text { hypotension, nausea and } \\
\text { vomiting } 43\end{array}$ \\
\hline Propofol & GABA-A receptor agonist & $\begin{array}{l}1-2.5 \mathrm{mg} / \mathrm{kg} \text { IV bolus } \\
50-250 \mu \mathrm{gg} / \mathrm{kg} / \mathrm{min} \text { IV infusion }\end{array}$ & $\begin{array}{l}\text { Onset: } 30 \mathrm{~s} \\
\text { Duration: } 5-15 \mathrm{~min}\end{array}$ & $\begin{array}{l}\text { Significant decreases in } \\
\text { systemic vascular resistance, } \\
\text { stroke volume, and cardiac } \\
\text { output } \\
\text { Causes respiratory depres- } \\
\text { sion; potent bronchodilator } \\
\text { Causes pain on injection }\end{array}$ \\
\hline Etomidate & GABA-A receptor agonist & $0.1-0.4 \mathrm{mg} / \mathrm{kg}$ IV & $\begin{array}{l}\text { Onset: }<1 \mathrm{~min} \\
\text { Duration: } 5-15 \mathrm{~min}\end{array}$ & $\begin{array}{l}\text { Safe hemodynamic profile } \\
\text { but no analgesic effect } \\
\text { Associated with adrenal } \\
\text { suppression }(\sim 12 \mathrm{~h}) \text {, pain on } \\
\text { injection, postoperative } \\
\text { nausea and vomiting } 44\end{array}$ \\
\hline Ketamine & $\begin{array}{l}\text { Analog of phencyclidine } \\
\text { NMDA receptor antagonist }\end{array}$ & $\begin{array}{l}1-2 \mathrm{mg} / \mathrm{kg} \mathrm{IV} \\
3-4 \mathrm{mg} / \mathrm{kg} \mathrm{IM} \\
4-6 \mathrm{mg} / \mathrm{kg} \text { PO }\end{array}$ & $\begin{array}{l}\text { Onset: } 1 \mathrm{~min} \\
\text { Duration: } 30-60 \mathrm{~min} \\
\text { Onset: } 5 \mathrm{~min} \\
\text { Duration: } 30-60 \mathrm{~min} \\
\text { Onset: } 10-20 \mathrm{~min} \\
\text { Duration: } 30-90 \mathrm{~min}\end{array}$ & $\begin{array}{l}\text { Causes "dissociative anes- } \\
\text { thesia," in which patients are } \\
\text { unconscious with eyes open, } \\
\text { breathing spontaneously and } \\
\text { do not react to painful stim- } \\
\text { uli. Causes delirium, marked } \\
\text { nystagmus, hallucinations } 43 \\
\text { Anticholinergics may be used } \\
\text { to prevent increased } \\
\text { secretions } 44\end{array}$ \\
\hline Dexmedetomidine & Alpha-2 adrenergic agonist & $\begin{array}{l}1-2 \mu \mathrm{g} / \mathrm{kg} \text { IV bolus (over } 10 \mathrm{~min} \text { ) } \\
0.5-2 \mu \mathrm{g} / \mathrm{kg} / \mathrm{h} \text { infusion }\end{array}$ & $\begin{array}{l}\text { Onset: } 10 \text { min } \\
\text { Duration: Clinical } 30 \text { min-1 h } \\
\text { Half-life: } 1.5-3 \mathrm{~h}^{44}\end{array}$ & $\begin{array}{l}\text { Limited respiratory antide- } \\
\text { pressant effects } \\
\text { Side effects are bradycardia, } \\
\text { hypotension, } 43 \\
\text { dose-dependent. } \\
\text { Mimics natural sleep } \\
\text { Caution with digitalis } \\
\text { medications }\end{array}$ \\
\hline
\end{tabular}

Abbreviations: IM, intramuscular; IV, intravenous; PO, per os. 


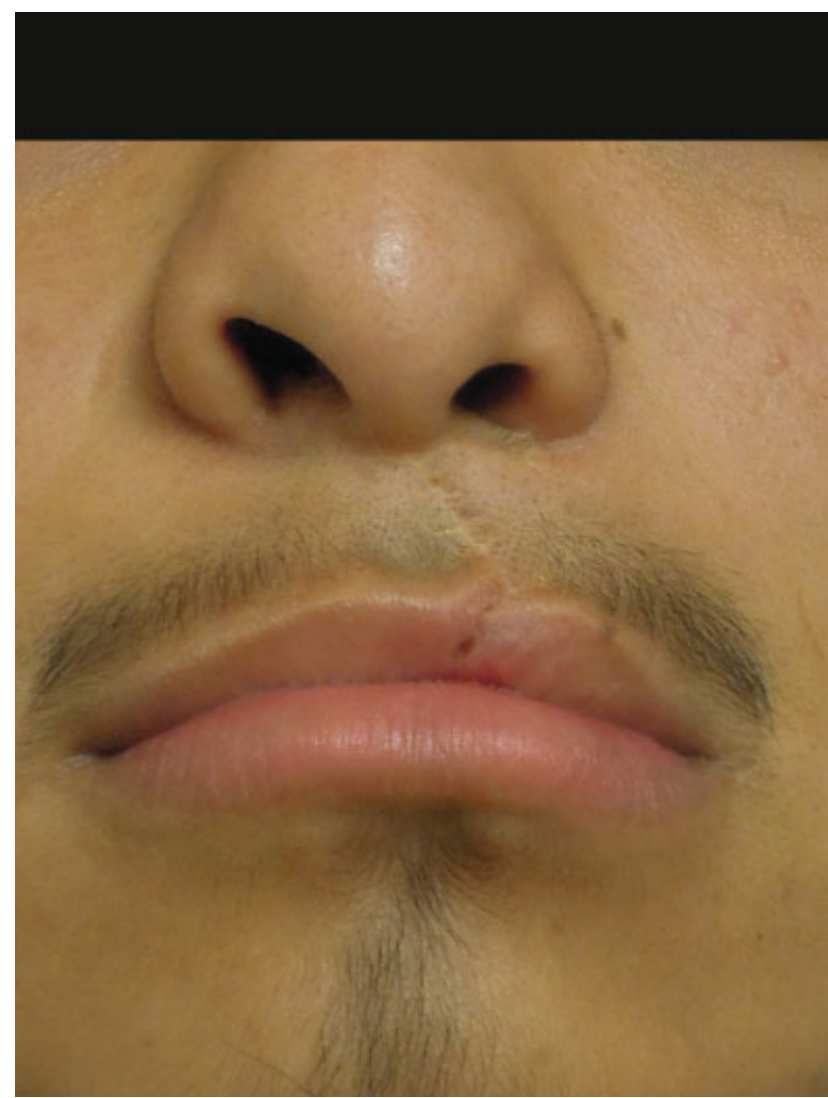

Fig. 5 Left nasal obstruction presenting after prior repair of left unilateral cleft lip/nasal deformity.

school age to young adulthood for definitive treatment (-Fig.8). Several reconstructive options have been proposed to manage columellar necrosis including full-thickness skin graft, composite auricular graft and local flaps from the nose, upper lip, or cheek. ${ }^{56-62}$ More complex deformities involving the soft tissue triangle or ala may incorporate these techni- ques or may require free grafts with local flaps or regional interpolated flaps from the forehead or cheek. ${ }^{63}$ Reports indicate that more than $10 \%$ of patients treated with nCPAP developed nasal injuries that could develop as soon as 7 days after the initiation of therapy. ${ }^{22}$ Children at greatest risk are preterm and/or low birthweight. Calls for routine use of hydrocolloid barriers to protect the nasal soft tissues are based on reports of decreased rates of nasal injury with their routine use in patients on nCPAP. ${ }^{21,64-66}$ The patient in - Fig. 9 presented at age 18 years with a right nasal obstruction and a secondary nasal deformity following nCPAP treatment as a neonate. The right alar base is medialized, there is a scar of the soft tissue triangle and depression of the alar rim. Reconstruction included release of the scar of the soft tissue facet, placement of an auricular cartilage rim graft, and lateralization of the ala and widening of the nostril sill using a peri-alar cheek flap (-Fig. 10). A review of patients with nasal injuries secondary to CPAP use reported that the majority of patients had more than one procedure and the mean age of the initial procedure was 7.2 years. ${ }^{67}$

Lacerations of the nasal base may occur during childbirth. A forceps-assisted delivery or other instrument-related insult could result in a soft tissue injury. Immediate recognition and repair or regular wound care are required to prevent scar formation. Scar contraction of the alar rim can result in retraction or cicatricial scar formation leading to vestibular stenosis. ${ }^{68-70}$ In a neonate who is an obligate nasal breather, nostril stenosis can have significant airway consequences. The case in - Fig. 11 presented after a traumatic delivery resulted in a laceration across the nasal base, extending onto the columella. The laceration was not immediately repaired and thick scabbing formed in the area followed by scar contracture weeks later. The patient presented to the pediatrician with increased work of breathing during feeding. Operative management for this case involved submucosal debridement of the scar, nostril dilation, triamcinolone
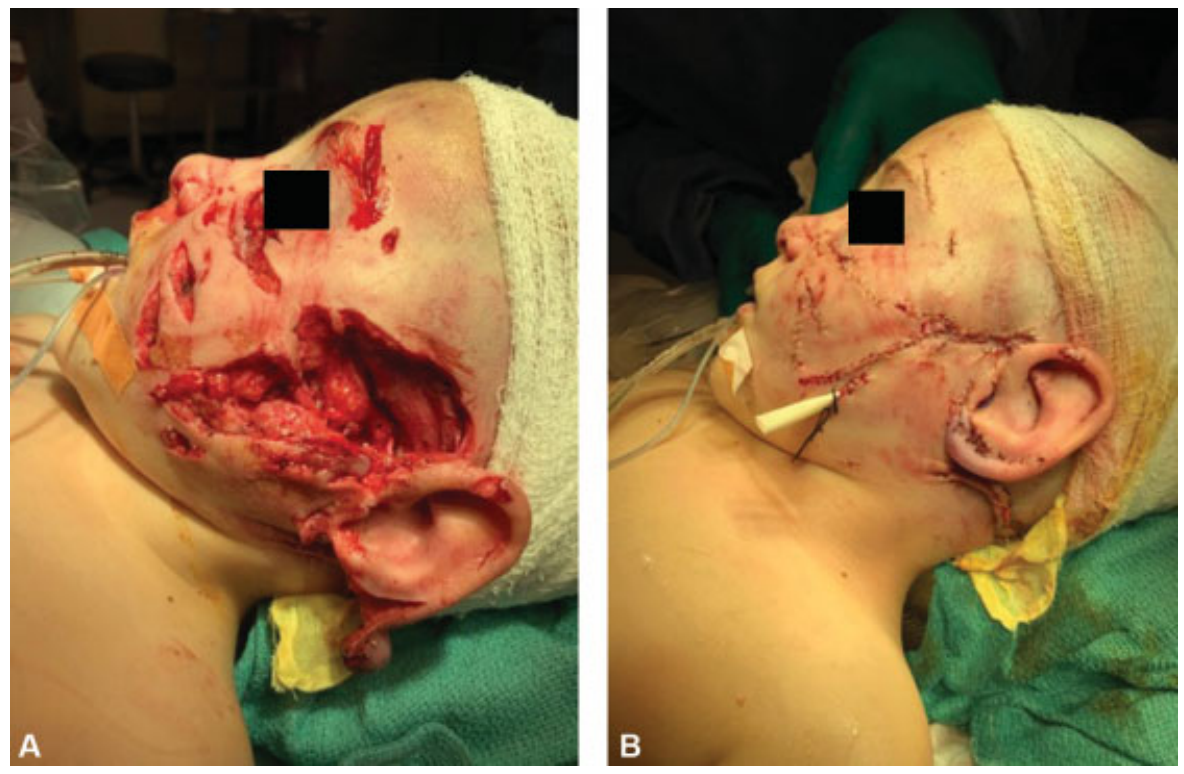

Fig. 6 Severe soft tissue trauma after penetrating wounds to the cheek with exposed facial nerve branch: (A) presentation and (B) postoperative view. 

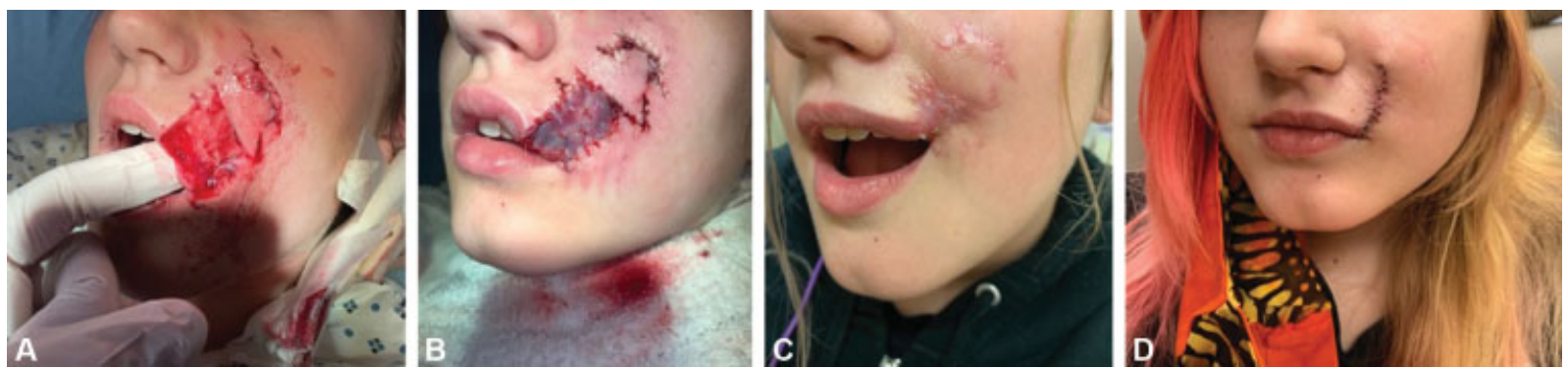

Fig. 7 Use of dermal allograft delayed repair of wound with significant tissue loss after dog bite to the perioral area: (A) presentation, (B) postoperative view, (C) well-incorporated graft 6 months postinjury, and (D) delayed definitive repair.

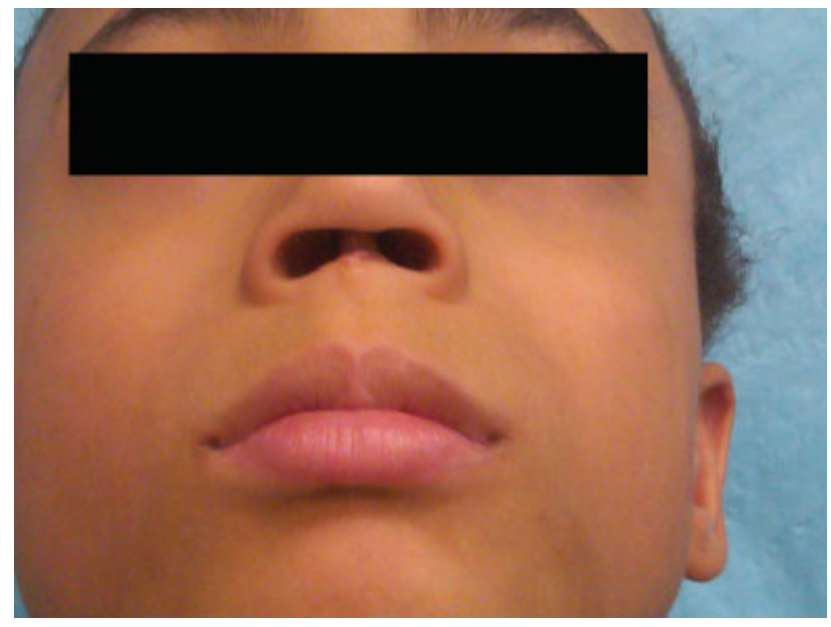

Fig. 8 Child presenting with columellar necrosis after neonatal continuous positive airway pressure injury.
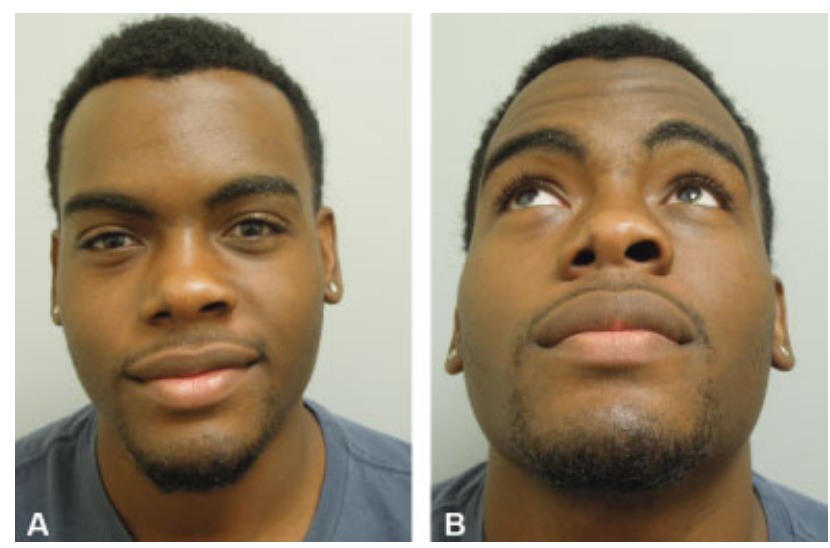

Fig. 9 Young adult with right nasal obstruction and secondary nasal deformity after neonatal continuous positive airway pressure injury: (A) Frontal view and (B) base view. Reproduced with permission from Timashpolsky and Butts. ${ }^{75}$

injection of the scar bed, and placement of a nostril conformer (-Fig. 12). A second Kenalog injection and dilation was performed 2 months later and the patient used the nostril conformer for 4 months. His 6 months and 4 years follow-up results are shown (-Fig. 13). No further procedures have been required. Early conservative management focusing on scar release can improve nostril diameter and prevent scar restriction on future nasal growth. ${ }^{71-73}$

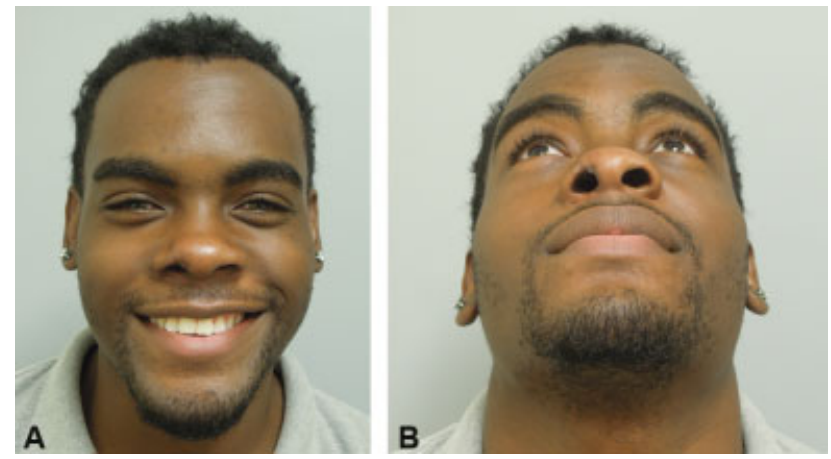

Fig. 10 Postoperative view after release of soft tissue facet scar, auricular cartilage rim graft, and use of peri-alar cheek flap to lateralize ala and widen nostril sill: (A) frontal view and (B) base view. Reproduced with permission from Timashpolsky and Butts. ${ }^{75}$

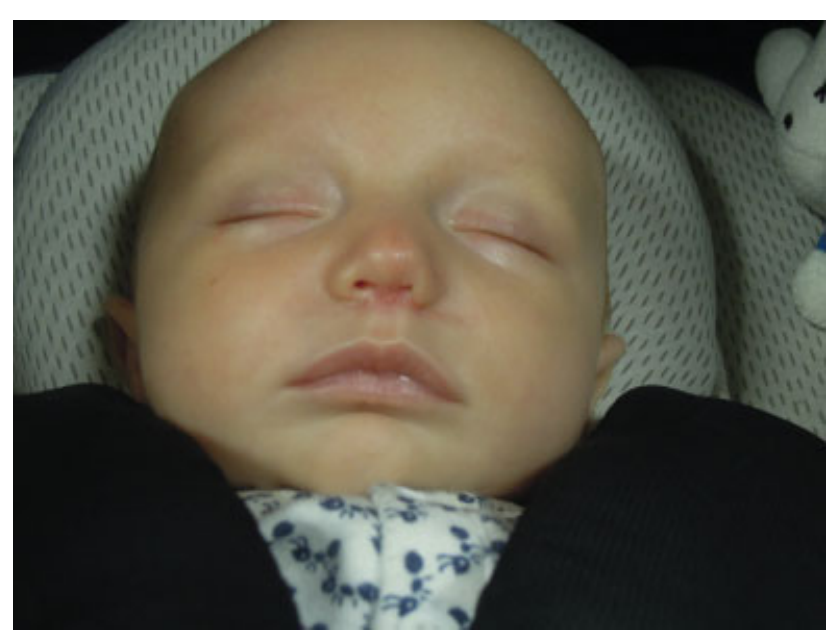

Fig. 11 Nostril stenosis due to laceration after traumatic delivery of newborn with delayed presentation.

\section{Conclusion}

Pediatric patients are vulnerable to soft tissue injuries of the face with some unique causes that require continued attention to preventive measures. Some of the most vulnerable patients are premature, low-birth weight infants who must be protected from postnatal facial injuries that may be the unfortunate sequalae of life-saving medical interventions. It is important to advocate for regulations that will keep children safe including continued support for protections in automobiles and during sports activities. Parents and the 


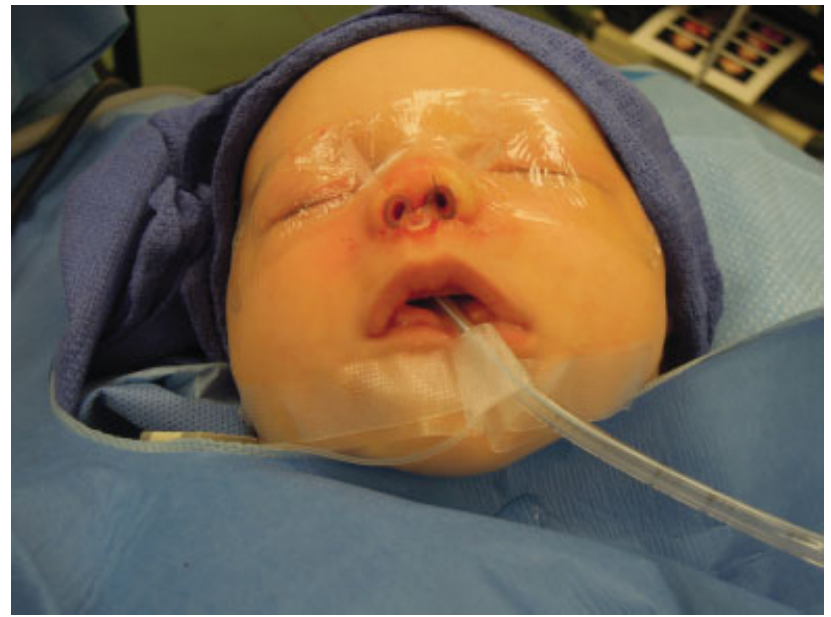

Fig. 12 Management of traumatic neonatal nostril stenosis with submucosal scar debridement, Kenalog injection to scar bed, and placement of nostril conformer.
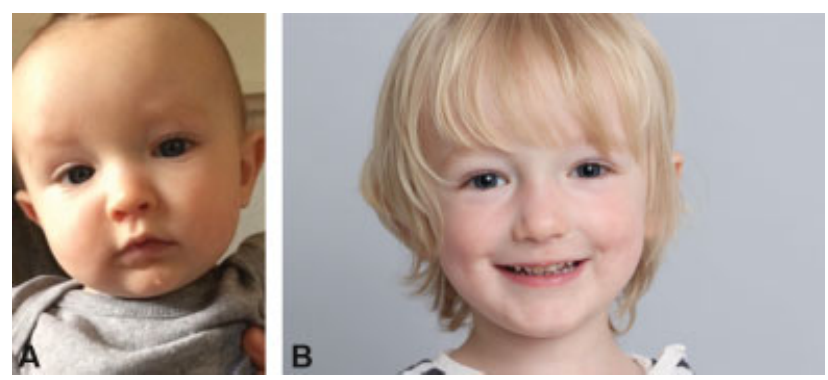

Fig. 13 Postoperative views after repair of nostril stenosis: (A) 6 months follow-up and (B) 4 years follow-up.

public must continue to be educated about the dangers that dogs pose to young children. Staged reconstructive procedures and long follow-up periods are important aspects of care for complex facial wounds in the pediatric population.

Conflict of Interest

None declared.

\section{References}

1 Collao-González C, Carrasco-Labra A, Sung-Hsieh HH, CortésAraya J. Epidemiology of pediatric facial trauma in Chile: a retrospective study of 7,617 cases in 3 years. Med Oral Patol Oral Cir Bucal 2014;19(02):e99-e105

2 Haug RH, Foss J. Maxillofacial injuries in the pediatric patient. Oral Surg Oral Med Oral Pathol Oral Radiol Endod 2000;90(02): 126-134

3 Gassner R, Tuli T, Hächl O, Moreira R, Ulmer H. Craniomaxillofacial trauma in children: a review of 3,385 cases with 6,060 injuries in 10 years. J Oral Maxillofac Surg 2004;62(04):399-407

4 Guice KS, Cassidy LD, Oldham KT. Traumatic injury and children: a national assessment. J Trauma 2007;63(6, Suppl):S68-S80, discussion S81-S86 10.1097/TA.0b013e31815acbb6 Erratum in: J Trauma. 2010 Oct;69(4):1008. PMID: 18091214

5 Vasconez HC, Buseman JL, Cunningham LL. Management of facial soft tissue injuries in children. J Craniofac Surg 2011;22(04):1320-1326

6 Hogg NJ. Primary and secondary management of pediatric soft tissue injuries. Oral Maxillofac Surg Clin North Am 2012;24(03): 365-375
7 Lim LH, Kumar M, Myer CM III. Head and neck trauma in hospitalized pediatric patients. Otolaryngol Head Neck Surg 2004;130(02):255-261

8 Adams CM, Morris CE, Salcedo ES, Holmes JF. Dissemination of a child passenger safety program through trauma center-community partnerships. J Trauma Nurs 2017;24(05):300-305

9 Svider PF, Chen M, Burchhardt D, et al. The vicious cycle: pediatric facial trauma from bicycling. Otolaryngol Head Neck Surg 2016; 154(02):371-376

10 Zielinski AE, Rochette LM, Smith GA. Stair-related injuries to young children treated in US emergency departments, 19992008. Pediatrics 2012;129(04):721-727

11 Kundal VK, Debnath PR, Sen A. Epidemiology of pediatric trauma and its pattern in urban India: a tertiary care hospital-based experience. J Indian Assoc Pediatr Surg 2017;22(01): 33-37

12 Day C, Stolz U, Mehan TJ, Smith GA, McKenzie LB. Diving-related injuries in children $<20$ years old treated in emergency departments in the United States: 1990-2006. Pediatrics 2008;122(02): e388-e394

13 Wang BS, Smith SL, Pereira KD. Pediatric head and neck trauma from all-terrain vehicle accidents. Otolaryngol Head Neck Surg 2007;137(02):201-205

14 Scheffler P, Wolter NE, Namavarian A, Propst EJ, Chan Y. Contact sport related head and neck injuries in pediatric athletes. Int $\mathrm{J}$ Pediatr Otorhinolaryngol 2019;121:6-9

15 Kaye AE, Belz JM, Kirschner RE. Pediatric dog bite injuries: a 5year review of the experience at the Children's Hospital of Philadelphia. Plast Reconstr Surg 2009;124(02):551-558

16 Rothe K, Tsokos M, Handrick W. Animal and human bite wounds. Dtsch Arztebl Int 2015;112(25):433-442, quiz 443

17 Wu PS, Beres A, Tashjian DB, Moriarty KP. Primary repair of facial dog bite injuries in children. Pediatr Emerg Care 2011;27(09): 801-803

18 Gurunluoglu R, Glasgow M, Arton J, Bronsert M. Retrospective analysis of facial dog bite injuries at a level I trauma center in the Denver metro area. J Trauma Acute Care Surg 2014;76(05):1294-1300

19 ASPS Media Press Release. National Dog Bite Prevention Week. Prevention Is Best Cure for Dog Bites. . May 17Y23, 2009. Accessed March 11, 2021 at: http://www.plasticsurgery.org/Media/Press_Releases/National_Dog_Bite_Prevention_Week_-_Prevention_is_Best_Cure_for_Dog_Bites.html

20 Nelson KA. One city's experience: why pit bulls are more dangerous and breed-specific legislation in justified. Municipal Lawyer 2005;46:12

21 Xie LH. Hydrocolloid dressing in preventing nasal trauma secondary to nasal continuous positive airway pressure in preterm infants. World J Emerg Med 2014;5(03):218-222

22 Jatana KR, Oplatek A, Stein M, Phillips G, Kang DR, Elmaraghy CA. Effects of nasal continuous positive airway pressure and cannula use in the neonatal intensive care unit setting. Arch Otolaryngol Head Neck Surg 2010;136(03):287-291

23 Best Practice Guidelines for Trauma Center Recognition of Child Abuse. Elder Abuse, and Intimate Partner Violence. ACS Trauma Qual Prog 2019. Accessed April 6, 2021 at: https://www.facs. org/-/media/files/quality-programs/trauma/tqip/abuse_guidelines.ashx

24 Greywoode JD, Pribitkin EA, Krein H. Management of auricular hematoma and the cauliflower ear. Facial Plast Surg 2010;26(06): 451-455

25 Hao S, Angster K, Hubbard F, Greywoode J, Vakharia KT. Ear scaffold reconstruction using ultrasonic aspirator for cauliflower ear. Cleft Palate Craniofac J 2018;55(04):619-621

26 Talan DA, Citron DM, Abrahamian FM, Moran GJ, Goldstein EJEmergency Medicine Animal Bite Infection Study Group. Bacteriologic analysis of infected dog and cat bites. N Engl J Med 1999;340(02):85-92 
27 Cummings P, Del Beccaro MA. Antibiotics to prevent infection of simple wounds: a meta-analysis of randomized studies. Am J Emerg Med 1995;13(04):396-400

28 Elliott DJ, Zaoutis TE, Troxel AB, Loh A, Keren R. Empiric antimicrobial therapy for pediatric skin and soft-tissue infections in the era of methicillin-resistant Staphylococcus aureus. Pediatrics 2009;123(06):e959-e966

29 American Academy of Pediatrics, Committee on Infections Diseases. Antimicrobial prophylaxis in pediatric surgical patients. In: Kimberlin DW, Brady MT, Jackson MA, Long SS, et al, eds. Red Book: 2015 Report of the Committee on Infectious Disease. 30th ed. Elk Grove, IL: American Academy of Pediatrics; 2015:824Y828

30 Manning SE, Rupprecht CE, Fishbein D, et al; Advisory Committee on Immunization Practices Centers for Disease Control and Prevention (CDC) Human rabies prevention-United States, 2008: recommendations of the Advisory Committee on Immunization Practices. MMWR Recomm Rep 2008;57(RR-3):1-28

31 Black KD, Cico SJ, Caglar D. Wound management. Pediatr Rev 2015;36(05):207-215, quiz 216

32 Clinical Effectiveness Committee. Guideline for Ketamine Sedation of Children in Emergency Departments. London: The Royal College of Emergency Medicine; 2009

33 Webber J, Ilahi N, Lloyd G. Retrospective analysis of process times for lacerations of the face in children: procedural sedation or general anaesthesia? Br J Oral Maxillofac Surg 2016;54(06):715-716

34 Green SM, Roback MG, Krauss BS, et al. Unscheduled procedural sedation: a multidisciplinary consensus practice guideline. Ann Emerg Med 2019;73(05):e51-e65

35 Coté CJ, Wilson; SAMERICAN ACADEMY OF PEDIATRICS; AMERICAN ACADEMY OF PEDIATRIC DENTISTRY. Guidelines for monitoring and management of pediatric patients before, during, and after sedation for diagnostic and therapeutic procedures. Pediatrics 2019;143(06):e20191000

36 Apfelbaum JL, Schaumburg AM, et al. Practice guidelines for preoperative fasting and the use of pharmacologic agents to reduce the risk of pulmonary aspiration: application to healthy patients undergoing elective procedures: an updated report by the American Society of Anesthesiologists task force on preoperative fasting and the use of pharmacologic agents to reduce the risk of pulmonary aspiration. Anesthesiology 2017;126(03):376-393

37 American Society of Anesthesiology Committee on Quality Management and Departmental Administration. Continuum of Depth of Sedation: Definition of General Anesthesia and Levels of Sedation/Analgesia. 2019

38 Malviya S, Voepel-Lewis T, Tait AR. Adverse events and risk factors associated with the sedation of children by nonanesthesiologists. [abstract]Anesth Analg 1997;85(06):1207-1213

39 Cravero JP, Beach ML, Blike GT, Gallagher SM, Hertzog JHPediatric Sedation Research Consortium. The incidence and nature of adverse events during pediatric sedation/anesthesia with propofol for procedures outside the operating room: a report from the Pediatric Sedation Research Consortium. [abstract]Anesth Analg 2009;108(03):795-804

40 Coté CJ, Karl HW, Notterman DA, Weinberg JA, McCloskey C. Adverse sedation events in pediatrics: analysis of medications used for sedation. [abstract]Pediatrics 2000;106(04): 633-644

41 Jain R, Petrillo-Albarano T, Parks WJ, Linzer JF Sr, Stockwell JA. Efficacy and safety of deep sedation by non-anesthesiologists for cardiac MRI in children. [abstract]Pediatr Radiol 2013;43(05): 605-611

42 Malviya S, Voepel-Lewis T, Ludomirsky A, Marshall J, Tait AR. Can we improve the assessment of discharge readiness?: A comparative study of observational and objective measures of depth of sedation in children [abstract]Anesthesiology 2004;100(02): 218-224

43 Barash PG, Cullen BF, Stoelting RK, et al. Clinical Anesthesia. 8th edition Philadelphia: Wolters Kluwer; 2017
44 Cravero JP, Kaplan RF, Landrigan-Ossar M, Coté CJ. Sedation for diagnostic and therapeutic procedures outside the operating room. In: Coté CJ, Lerman J, Anderson BJ, eds. Coté and Lerman's A Practice of Anesthesia for Infants and Children. Philadelphia: Elsevier; 2019:1109-1127

45 Cole P, Hammoudeh JA, Habal MB, Thaller SR. Pediatric soft tissue injuries to the head and neck. In: Bentz ML, Bauer BS, Zuker RM, eds. Principles and Practice of Pediatric Plastic Surgery. St. Louis: Quality Medical Publishing; 2008:213-227

46 Greives MR, Camison L, Losee JE. Evidence-based medicine: unilateral cleft lip and nose repair. Plast Reconstr Surg 2014; 134(06):1372-1380

47 Pawar SS, Wang TD. Secondary cleft rhinoplasty. JAMA Facial Plast Surg 2014;16(01):58-63

48 Mohler LR. Unilateral cleft lip repair. Plast Reconstr Surg 1987;80 (04):511-517

49 Barillas I, Dec W, Warren SM, Cutting CB, Grayson BH. Nasoalveolar molding improves long-term nasal symmetry in complete unilateral cleft lip-cleft palate patients. Plast Reconstr Surg 2009; 123(03):1002-1006

50 Lackmann GM, Draf W, Isselstein G, Töllner U. Surgical treatment of facial dog bite injuries in children. J Craniomaxillofac Surg 1992;20(02):81-86

51 Humphrey CD, Kriet JD. Nerve repair and cable grafting for facial paralysis. Facial Plast Surg 2008;24(02):170-176

52 Kretlow JD, McKnight AJ, Izaddoost SA. Facial soft tissue trauma. Semin Plast Surg 2010;24(04):348-356

53 Futran ND, Farwell DG, Smith RB, Johnson PE, Funk GF. Definitive management of severe facial trauma utilizing free tissue transfer. Otolaryngol Head Neck Surg 2005;132(01):75-85

54 Gulati RD, Faraci N, Butts SC. Neonatal ear molding. Laryngoscope 2021;131(02):E423-E427

55 Timashpolsky A, Butts SC. Nasal continuous positive airway pressure injuries. JAMA Facial Plast Surg 2019;21(02): 165-166

56 Sherris DA, Fuerstenberg J, Danahey D, Hilger PA. Reconstruction of the nasal columella. Arch Facial Plast Surg 2002;4(01): 42-46

57 Chang CS, Swanson JW, Wilson A, Low DW, Bartlett SP. Columellar reconstruction following nasal continuous positive airway pressure injury. Plast Reconstr Surg 2018;141(01):99e-102e

58 Constantian MB. An alar base flap to correct nostril and vestibular stenosis and alar base malposition in rhinoplasty. Plast Reconstr Surg 1998;101(06):1666-1674

59 Smith V, Pappay FA. Surgical options in columellar reconstruction. Otolaryngol Head Neck Surg 1999;120(06):947-951

60 Yao Y, Robertson C, Lee K, Somani AK. Crescentic alar myocutaneous island pedicle flap for reconstructing columellar defects. Dermatol Surg 2013;39(11):1699-1702

61 Yamawaki Y. Para-alar crescentic subcutaneous pedicle flap for severe stenosis of anterior nares. Am J Otolaryngol 2006;27(03): 211-213

62 Jayaratne YSN, Zwahlen RA, Htun SY, Bütow KW. Columella pressure necrosis: a method of surgical reconstruction and its long-term outcome. BMJ Case Rep 2014;2014:bcr2013203132

63 Son D, Kwak M, Yun S, Yeo H, Kim J, Han K. Large auricular chondrocutaneous composite graft for nasal alar and columellar reconstruction. Arch Plast Surg 2012;39(04):323-328

64 Burget G. Aesthetic Reconstruction of the Child's Nose. Chicago: Gary Burget Publisher; 2012

65 Boyar V. Pressure injuries of the nose and columella in preterm neonates receiving noninvasive ventilation via a specialized nasal cannula: a retrospective comparison cohort study. J Wound Ostomy Continence Nurs 2020;47(02):111-116

66 Imbulana DI, Owen LS, Dawson JA, Bailey JL, Davis PG, Manley BJ. A randomized controlled trial of a barrier dressing to reduce nasal injury in preterm infants receiving binasal noninvasive respiratory support. J Pediatr 2018;201:34-39.e3 
67 Dai T, Lv L, Liu X, Chen J, Ye Y, Xu L. Nasal pressure injuries due to nasal continuous positive airway pressure treatment in newborns: a prospective observational study. J Wound Ostomy Continence Nurs 2020;47(01):26-31

68 Li Y, Sepulveda A, Buchanan EP. Late presenting nasal deformities after nasal continuous positive airway pressure injury: 33year experience. J Plast Reconstr Aesthet Surg 2015;68(03): 339-343

69 Daines SM, Hamilton GS III, Mobley SR. A graded approach to repairing the stenotic nasal vestibule. Arch Facial Plast Surg 2010; 12(05):332-338

70 Kotzur A, Gubisch W, Meyer R. Stenosis of the nasal vestibule and its treatment. Aesthetic Plast Surg 1999;23 (02):86-92
71 Karen M, Chang E, Keen MS. Auricular composite grafting to repair nasal vestibular stenosis. Otolaryngol Head Neck Surg 2000;122 (04):529-532

72 Smith LP, Roy S. Treatment strategy for iatrogenic nasal vestibular stenosis in young children. Int J Pediatr Otorhinolaryngol 2006;70 (08):1369-1373

73 Daya M. Nostril stenosis corrected by release and serial stenting. J Plast Reconstr Aesthet Surg 2009;62(08):1012-1019

74 Butts SC, Brown D, Discolo C, et al. Otolaryngology. In: Shah B, ed. Atlas of Pediatric Emergency Medicine. 3rd ed. New York, NY: McGraw-Hill; 2019:439

75 Timashpolsky A, Butts SC. Nasal continuous positive airway pressure injuries: a clinical challenge. JAMA Facial Plastic Surg 2019;21(02):165-166 